Maria Anna Jankowska

\title{
A call for sustainable library operations and services \\ A response to ACRL's 2007 environmental scan
}

$\mathrm{I}_{\mathrm{l}}^{\mathrm{n}}$ ACRL's "Environmental Scan 2007" (released January 2008 by the ACRL Research Committee), there was no mention of the environmental sustainable development of academic libraries. ${ }^{1}$ I find the omission disconcerting as I watch piles of printed e-mail and unwanted books thrown out, library users printing page after page of documents, old computers and technologies being discarded, and no serious accounting of what type and how much energy is used in academic libraries on a daily basis.

Academic libraries are ironic places of contradiction: environmental consumption within libraries is skyrocketing, but the very model of a library is built on sustainability. The economic model libraries have established based on the sharing of resources rather than unnecessary duplication was developed as a logical consequence of the increasing costs of scholarly publications and the changing needs of library users.

Today the tradition of sustainability has been overshadowed as digitization, collection development, and providing adequate technologies have become core library missions. Academic libraries must keep up with user demands and needs, but that does not mean that we should turn our backs on the very concepts that libraries were founded upon. This is not even a matter of maintaining the past; it is an issue of developing and planning for a future that is realistic, achievable, and most importantly_sustainable.

The current rate of environmental consumption within academic libraries cannot be maintained and is actively damaging the environment around us. Furthermore, library consumption is becoming economically unsustainable, and through various fees on users, is threatening the core library mission of providing free and open access to information for all users.

The environmental scan presents recent situations and future trends in academic and research libraries in a section entitled "Top ten assumptions for the future of academic libraries and librarians," which stresses the increase of digitizing collections, technology, intellectual property, and business models for higher education. Yet just as the digital and technological revolutions have made a significant impact on the mission and methods of libraries, these new trends are also seriously threatening the sustainability of libraries.

Books and journal articles are no longer simply checked out, read, and returned. Now multiple users can on multiple occasions, download, print, and keep the same information. It is no longer enough for a library to have a basic collection; instead, the expansion, creation, and preservation of collections have taken on new horizons in the library world. The resources and commodities (water, electricity, gas, land, and paper) consumed in these processes place a large burden on library budgets. This burden is in turn being passed on to users as small fees begin to add up, threatening the core library concept of free access to information.

Maria Anna Jankowska is social sciences librarian at University of California-Los Angeles, e-mail: majankowska@library.ucla.edu

@ 2008 Maria Anna Jankowska 
Even in this so-called "paperless society," the usage of paper, electronic, and hazardous waste is growing drastically, causing a major disparity between the goal of an environmentally sustainable model for libraries and the reality of their daily operations and services.

Every library shipping room almost daily receives new books, periodicals, interlibrary loan orders, catalogs from a variety of publishers, slip orders from approval plans, correspondence, and a variety of other mail. Furthermore, each library throws away or rarely recycles weeded and unneeded printed books, government documents, magazines, newspapers, bound periodicals, junk mail, office computer paper, and general waste. As the number of digital projects and functions escalate, libraries are faced with increasing energy costs, as well as the need to recycle unwanted equipment, outdated computers, CDs, computers disks, and used computer paper.

What percentage of daily library shipments ends up in garbage bins? What percentage of publisher catalogs coming to libraries are produced on recycled paper? How much computer paper is used on average per library employee and per library user? How much energy do our computers and printers use up? Are ink cartridges recycled, and do we use inks that are good for the environment? Do we know how much solid waste a library generates? Do we have any economic model for recovering costs of printing and copying in libraries? And finally, how is the library recuperating these costs in the form of printing fees and other taxes upon the users? Are these methods fair and in line with the library's mission of free and open access to information for all users?

The sustainable development of collections and library services should become important components of academic library operations. A full and all-encompassing notion of sustainability as a goal of academic libraries is necessary to:

- promote relevant, quality information while helping users disseminate information and knowledge to a broad category of users and provide equal access to all users,
- provide alternative access to costly commercial scientific sources, and

- teach environmental information literacy needed to promote the ideals of a sustainable future. ${ }^{2}$

Libraries must begin to focus on creating more responsible operational models in terms of environmental impact if they are to keep information open and free to all, and if they are to support broader goals of scholarly community sustainability. Unless both operational costs and environmental impact are reduced in the long-term, the continuous expansion and consumption of collections and services will result in limited access to information to a limited number of people.

Terry Link believes that only through sustainability and environmental education can higher education be transformed and saved from commercialization, and that by participating in the creation of a sustainable future, libraries can again be "the heart of the learning communities." ${ }^{3}$ We cannot continue to expand, produce, digitize, and consume without a serious look at the impacts of our actions on the environment and academic society around us.

\section{Notes}

1. ACRL's Environmental Scan 2007 is available atwww.acrl.org/ala/acrl/acrlpubs/whitepapers/Environmental_Scan_2.pdf.

2. Maria A. Jankowska, "Librarian's Contribution to Scholarly Communication and Environmental Literacy," The Serials Librarian 49 (4): 117-24.

3. Terry Link, "Transforming higher education through sustainability and environmental education," Issues in Science and Technology Librarianship, Spring 2000. Available at www. istl.org/00-spring/article4.html. $n$

\section{What do you think?}

Visit the June 2008 issue of CERL News online at www.acrl.org/c\&rlnews for a link to the transcript of the May 2008 ACRL OnPoint chat on green libraries and to discuss sustainability issues. 